\title{
Cell-Volume Regulation by Swelling-Activated Chloride Current in Guinea-Pig Ventricular Myocytes
}

\author{
Shintaro YAMAMOTO, Keiko ISHIHARA, Tsuguhisa EHARA, and Takao SHIOYA \\ Department of Physiology, Saga Medical School, Saga, 849-8501 Japan
}

\begin{abstract}
The cell-volume regulation by swelling-activated $\mathrm{Cl}^{-}$current $\left(I_{\mathrm{Cl}, \text { swell }}\right)$ was studied in guinea pig ventricular myocytes, using a microscopic video-image analysis. We have previously shown that in ventricular cells depolarized in high- $\mathrm{K}^{+}\left(\left[\mathrm{K}^{+}\right]_{0}>45 \mathrm{mM}\right)$ solution, an activation of the cyclic AMP-dependent $\mathrm{Cl}^{-}$current $\left(I_{\mathrm{Cl}, \mathrm{cAMP}}\right)$ leads to cell swelling. We first investigated the mechanism underlying the $I_{\mathrm{Cl}, \mathrm{CAMP}}$-independent recovery (shrinkage) of the swollen cells. They shrank when the membrane potential $\left(V_{\mathrm{m}}\right)$ was made negative to the equilibrium potential of $\mathrm{Cl}^{-}$ $\left(E_{\mathrm{Cl}}\right)$ by lowering $\left[\mathrm{K}^{+}\right]_{0}$ or $\left[\mathrm{Cl}^{-}\right]_{0}$ in the high- $\mathrm{K}^{+}$solution. This shrinkage was attenuated by the inhibitors (DIDS, glibenclamide, furosemide) of swelling-activated $\mathrm{Cl}^{-}$current $\left(I_{\mathrm{Cl} \text {,swell }}\right)$. These findings suggested an involvement of $I_{\mathrm{Cl} \text {,swell }}$ in the observed isosmotic cell shrinkage. On the other hand, an application of hyposmotic $(70 \%$ of control) solution to the cells at normal $\left[\mathrm{K}^{+}\right]_{0}$
\end{abstract}

$\left(E_{\mathrm{Cl}}>V_{\mathrm{m}}\right)$ induced a cell swelling, and the swollen cells underwent a slight but definite spontaneous cell shrinkage during hyposmotic challenge, indicating the operation of the mechanism of regulatory volume decrease (RVD). This RVD was pronounced at low $\left[\mathrm{Cl}^{-}\right]_{0}$, at which $E_{\mathrm{Cl}}$ was much more positive than $V_{\mathrm{m}}$. On the contrary, when the hyposmotic solution was applied to the cells at high $\left[\mathrm{K}^{+}\right]_{0}$, at which $E_{\mathrm{Cl}}$ was negative to $V_{\mathrm{m}}$, the cells swelled vigorously and monotonically without showing RVD, the swelling being much greater than that seen at normal $\left[\mathrm{K}^{+}\right]_{0}$. Both the RVD at normal $\left[\mathrm{K}^{+}\right]_{0}$ and the extra cell swelling at high $\left[\mathrm{K}^{+}\right]_{0}$ were suppressed by DIDS. These results suggest that $I_{\mathrm{Cl} \text {,swell }}$ activated by cell swelling can shrink or inflate the cardiac cells under hyposmotic as well as isosmotic conditions, depending on $V_{\mathrm{m}}$ and $E_{\mathrm{Cl}}$. [The Japanese Journal of Physiology 54: 31-38, 2004]

Key words: cell volume regulation, swelling-activated $\mathrm{Cl}^{-}$current, $\mathrm{RVD}$, ventricular cell.

A wide variety of mammalian cell types have
swelling-activated $\mathrm{Cl}^{-}$channels (or volume expan-
sion-sensing $\mathrm{Cl}^{-}$channels), and the current through
these channels $\left(I_{\mathrm{Cl}, \text { swell }}\right.$ is thought to play an important
role in cell-volume regulation, particularly in the reg-
ulatory volume decrease (RVD) (for review see
Sarkadi and Parker [1], Strange et al. [2], Okada [3],
and Wright and Rees [4]). Since $I_{\mathrm{Cl}, \text { swell }}$ has been iden-
tified in many types of cardiac cells (for review see
Vandenberg et al. [5] and Sorota [6]), it is expected
that cardiac $I_{\mathrm{Cl}, \text { swell }}$ also contributes to cell-volume reg-
ulation. Several studies have been conducted to inves-
tigate the link between the activation of $I_{\mathrm{Cl}, \text { swell }}$ and the
associated cell-volume change in cardiac cells. Cul-

tured embryonic chick heart cells, in which $I_{\mathrm{Cl}, \text { swell }}$ can be recorded, have been shown to undergo a sizable RVD during hyposmotic challenge [7]. The ventricular cells of newborn rat also have been shown to exhibit RVD, and this RVD was attenuated by the blockers of $I_{\mathrm{Cl} \text {,swell }}[8]$. For the role of $I_{\mathrm{Cl} \text {,swell }}$ in the cardiac cells of adult animals, studies on rabbit and dog cells are known. Although rabbit ventricular cells did not consistently exhibit RVD [9], the application of 9-anthracene carboxylic acid (9AC), an inhibitor of $I_{\mathrm{Cl} \text {,swell, }}$ to these cells enhanced their hyposmotic swelling [10]. Clemo et al. [11] recorded $I_{\mathrm{Cl}, \text { swell }}$ and the changes in cell volume simultaneously in dog ventricular cells during hyposmotic challenge. They showed 


\section{S. YAMAMOTO et al.}

that an application of 9AC inhibited $I_{\mathrm{Cl} \text {,swell }}$ and enhanced the cell swelling and that the latter enhancement was correlated with the decrease of $I_{\mathrm{Cl} \text {,swell }}$ produced by the drug. All these findings have been taken to indicate the involvement of $I_{\mathrm{Cl} \text {,swell }}$ in the observed changes in cell volume. However, the detailed relationship between the direction and magnitude of $I_{\mathrm{Cl}, \text { swell }}$ and the changes in cell volume are not yet fully understood.

As described above, the role of cardiac $I_{\mathrm{Cl} \text {,swell }}$ in volume regulation has been studied mainly in osmotically swollen cells. Cardiac cells can experimentally be swollen not only by hyposmotic challenge. It has been shown that in $\mathrm{K}^{+}$-depolarized cardiac cells, an activation of the cyclic AMP-dependent $\mathrm{Cl}^{-}$current $\left(I_{\mathrm{Cl}, \mathrm{cAMP}}[12-14]\right)$ leads to cell swelling under isosmotic conditions [15]. In the present study, we first searched for the role of $I_{\mathrm{Cl}, \text { swell }}$ in this type of cell swelling in guinea pig ventricular cells. Then we examined whether these cells exhibited any $I_{\mathrm{Cl}, \text { swell }}$-related change in their volume during hyposmotic challenge. The experiments were performed in consideration of the following. If a flux of $\mathrm{Cl}^{-}$ions across the membrane generated by the activation of $I_{\mathrm{Cl} \text {,swell }}$ with cofluxes of cations produces a change in cell volume, the change should vary depending on the direction and magnitude of $I_{\mathrm{Cl} \text {,swell }}$ : It should depend on the membrane potential and on the electrochemical potential gradient of $\mathrm{Cl}^{-}$ions. The results suggest that the cell swelling activates $I_{\mathrm{Cl} \text {,swell }}$ and that the activated $I_{\mathrm{Cl}, \text { swell }}$ induces RVD or an extra cell inflation, depending on the direction and magnitude of $I_{\mathrm{Cl}, \text { swell }}$.

\section{MATERIALS AND METHODS}

Cell preparation. Ventricular myocytes were isolated from guinea pig hearts following the standard enzymatic dissociation procedure [16]. The experimental protocol was approved by the Committee of Animal Welfare in Saga Medical School. The investigation conforms also with the Guiding Principles of the Physiological Society of Japan. In brief, guinea pigs (250-400 g body weight) were killed by a sodium pentobarbitone overdose $(100 \mathrm{mg} / \mathrm{kg}$ I.P.), and a thoracotomy was performed. The heart was quickly excised, cannulated through the aorta, and retrogradely perfused at $37^{\circ} \mathrm{C}$, initially with normal Tyrode solution for $5 \mathrm{~min}$, then with nominally $\mathrm{Ca}^{2+}$-free Tyrode solution for $5 \mathrm{~min}$, and finally with nominally $\mathrm{Ca}^{2+}$ free Tyrode solution containing $0.5 \mathrm{mg} \mathrm{ml}^{-1}$ collagenase (Wako, Osaka, Japan) for 6-12 min. The collagenase was then washed out of the heart with a high- $\mathrm{K}^{+}$, low- $\mathrm{Cl}^{-}$solution (KB solution [17]). The digested ventricle was dissected to disperse the cells in KB solution. Isolated myocytes were stored in this medium at $4^{\circ} \mathrm{C}$ until use.

Solutions and drugs. Normal Tyrode solution contained (mM) $140 \mathrm{NaCl}, 5.4 \mathrm{KCl}, 1.8 \mathrm{CaCl}_{2}, 0.5$ $\mathrm{MgCl}_{2}, 0.33 \mathrm{NaH}_{2} \mathrm{PO}_{4}, 5.5$ glucose, and 5.0 HEPES ( $\mathrm{pH}$ adjusted to 7.4 with $\mathrm{NaOH}$ ). The nominally $\mathrm{Ca}^{2+}$ free Tyrode solution used for cell isolation was prepared by simply omitting $\mathrm{CaCl}_{2}$ from the normal Tyrode solution. In the experiments of isosmotic cell swelling (Figs. 1-2), isosmotic solutions with different ion compositions were used. High- $\mathrm{KCl}$ or high-K-aspartate solution was made by replacing $140 \mathrm{mM} \mathrm{NaCl}$ in the nominally $\mathrm{Ca}^{2+}$-free Tyrode solution with $140 \mathrm{mM} \mathrm{KCl} \mathrm{(KCl} \mathrm{solution)} \mathrm{or} \mathrm{K-aspartate} \mathrm{(K-aspar-}$ tate solution), respectively. Low- $\mathrm{Na}^{+}$solution was prepared in a similar manner with $140 \mathrm{mM} \mathrm{N}$-methylD-glucamine-HCl (NMDG-Cl solution). For the experiments of hyposmotic cell swelling (Figs. 3-5), various types of isosmotic and hyposmotic solutions were prepared. The control isosmotic bathing solution contained (mM) $100 \mathrm{NaCl}, 80$ mannitol, $5.4 \mathrm{KCl}, 1.8$ $\mathrm{CaCl}_{2}, 0.5 \mathrm{MgCl}_{2}, 0.33 \mathrm{NaH}_{2} \mathrm{PO}_{4}, 5.5$ glucose, and 5.0 HEPES ( $\mathrm{pH}$ adjusted to 7.4 with $\mathrm{NaOH}$ ). To obtain high- $\mathrm{K}^{+}$isosmotic solution, $\mathrm{NaCl}$ in the control solution was totally replaced with $\mathrm{KCl}$, and $\mathrm{CaCl}_{2}$ was omitted. The standard hyposmotic solution with $70 \%$ osmolarity was prepared by omitting mannitol from the control bathing solution. When necessary, $\mathrm{NaCl}$ in this solution was totally replaced with $\mathrm{Na}$-aspartate to obtain low- $\mathrm{Cl}^{-}$hyposmotic solution. High- $\mathrm{K}^{+}$hyposmotic solution was prepared by omitting mannitol from the high- $\mathrm{K}^{+}$isosmotic solution. The drugs used were L-adrenaline (Daiichi, Tokyo, Japan), glibenclamide (Sigma, St. Louis, MO, USA), 4,4' -diisothiocyanostilbene-2,2'-disulphonate (DIDS; Sigma), and furosemide (Sigma). All experiments were done at $36.5 \pm 0.5^{\circ} \mathrm{C}$.

Videomicroscopy and image analysis. The method to measure the cell area on the videomicroscopic image was the same as described previously [15]. Isolated cells were allowed to settle onto the glass bottom of an experimental chamber mounted on an inverted microscope (Diaphot; Nikon, Tokyo, Japan). The chamber was continuously perfused with bathing solutions at the rate of $1.0-1.2 \mathrm{ml} \mathrm{min}^{-1}$. Microscopic images of the cell were recorded with a CCD video camera (CS3330; Tokyo Electronic, Tokyo, Japan) mounted on the side port of the microscope, which was equipped with a $\times 40$ objective and a $\times 1$ relay lens. Video images were captured at a $640 \times 480$ resolution and fed into a computer (Macintosh G3; Apple, Cupertino, CA, USA) through an 8- 
bit frame grabber (LG-3; Scion, Frederick, MD, USA). The captured images were processed by using NIH-image public domain software (NIH, Bethesda, MD, USA). Its outline macro detected cell boundary over the entire cell image by searching for pixels darker than a given threshold level and constructed the images of cell contour. The number of pixels included within the contour was a measure of the area occupied by the cell image. With a combination of this software and custom macros, the area of the cell image was calculated every $6 \mathrm{~s}$ during the experiments. It should be noted that the cell area is only a rough index of the cell volume. The validity of this method to estimate the cell volume was discussed in the previous paper [15].

Statistics. The data are expressed as mean \pm SEM; $n$ indicates the number of measurements. Statistical comparisons of the time course of changes in the cell area between two groups were made according to two-way repeated measures ANOVA (analysis of variance). Otherwise, comparisons were made using a Student's $t$-test for paired or unpaired data where appropriate. The differences were considered to be significant at $p<0.05$.

\section{RESULTS}

\section{$I_{\mathrm{Cl}, \text { swell }}$ and the isosmotic volume change}

It has been shown that in guinea pig ventricular cells that are immersed in isosmotic high- $\mathrm{KCl}\left(\left[\mathrm{K}^{+}\right]_{\mathrm{o}}\right.$ $>45 \mathrm{mM}$ ) solution, the activation of $I_{\mathrm{Cl}, \mathrm{cAMP}}$ by adrenaline leads to cell swelling [15]. The swelling is explained as follows. In such high- $\mathrm{KCl}$ solutions, the membrane potential $\left(V_{\mathrm{m}}\right)$ is positive to the equilibrium potential of $\mathrm{Cl}^{-}\left(E_{\mathrm{Cl}}\right)$. Therefore the activation of $I_{\mathrm{Cl}, \text { cAMP }}$ produces an influx of $\mathrm{Cl}^{-}$ions (outward $\left.I_{\mathrm{Cl}, \mathrm{cAMP}}\right)$, and the influx of $\mathrm{Cl}$, with a secondary influx of $\mathrm{K}^{+}$ions through $\mathrm{K}^{+}$channels, results in a net influx of $\mathrm{KCl}$, which leads to cell swelling [15]. It has been shown also that such adrenergically swollen cells shrink again when the bathing solution is switched from high $-\mathrm{K}^{+}$to normal $\mathrm{K}^{+}$solution (normal Tyrode) without adrenaline. This finding suggests the operation of an $I_{\mathrm{Cl}, \mathrm{cAMP}}$-independent volume-regulatory mechanism in the observed cell shrinkage. We first attempted to further characterize this isosmotic cell shrinkage.

In the experiments shown in Fig. 1A, the cells swollen by adrenaline in high- $\mathrm{KCl}$ solution were exposed to NMDG-Cl solution, which was $\mathrm{Cl}^{-}$rich and had normal $\left[\mathrm{K}^{+}\right]_{\mathrm{o}}(5.4 \mathrm{mM})$, in the absence of $I_{\mathrm{Cl}, \mathrm{cAMP}}$ activation. The cells shrank toward the control level in NMDG-Cl solution, as in normal Tyrode [15]. Thus
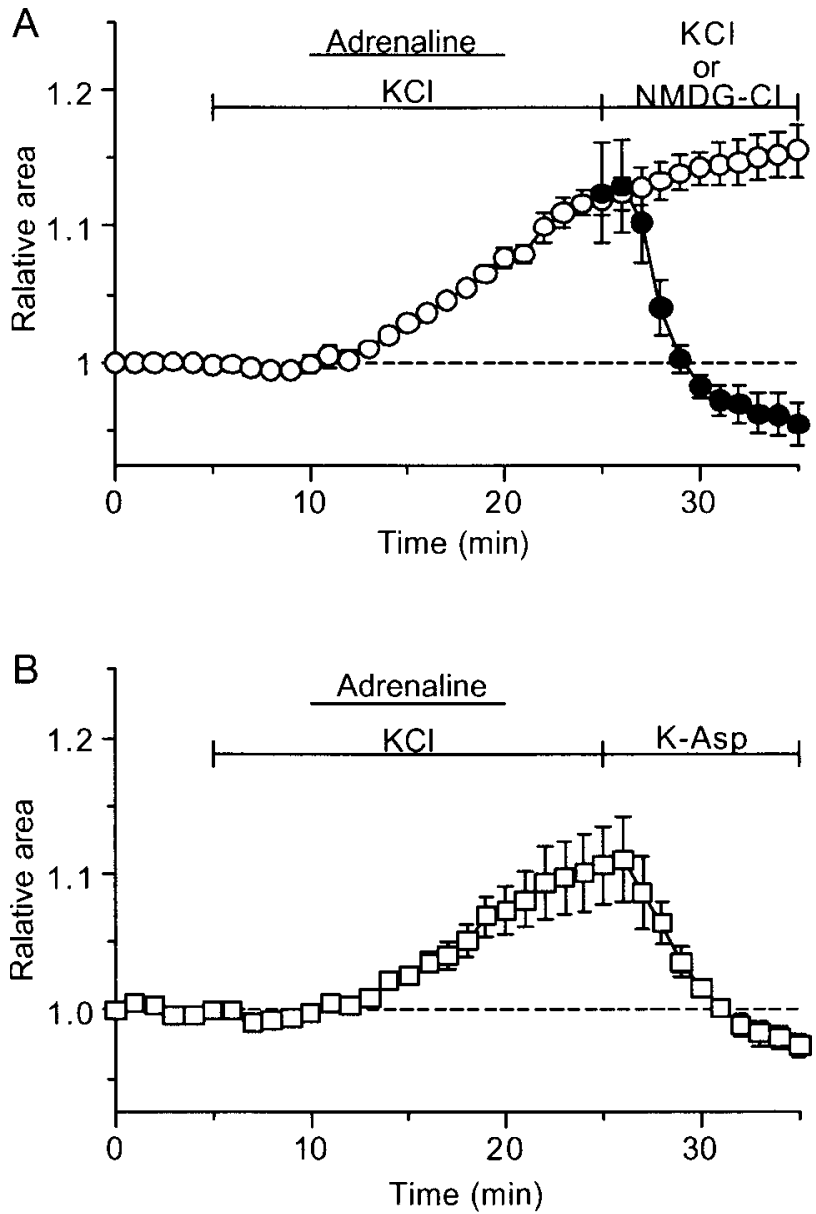

Fig. 1. Time course of the cell shrinkage observed when the cells inflated by adrenaline in high- $\mathrm{KCl}$ solution were bathed in NMDG-CI (A) or K-aspartate solution (B). The cells were initially bathed in normal Tyrode solution, then in high- $\mathrm{KCl}$ solution with $145.4 \mathrm{mM} \mathrm{KCl}(\mathrm{KCl}$; lower bar). Subsequently, adrenaline $(5.5 \mu \mathrm{M})$ was applied to the cells for $10 \mathrm{~min}$ (upper bar), which resulted in a swelling of the cells, and adrenaline was washed for $5 \mathrm{~min}$ thereafter. The perfusion with high- $\mathrm{KCl}$ solution was then continued (open circles in $A ; n=5$ ) or the cells were exposed to NMDG-Cl solution with $5.4 \mathrm{mM} \mathrm{K}^{+}$and $146.4 \mathrm{mM}$ $\mathrm{Cl}^{-}$(closed circles in $\mathrm{A} ; n=5$ ) or $\mathrm{K}$-aspartate solution with $145.4 \mathrm{mM} \mathrm{K}^{+}$and $6.4 \mathrm{mM} \mathrm{Cl}^{-}$(K-Asp; squares in $\mathrm{B}$; $\left.n=4\right)$. Each point represents mean \pm SEM. The data of the NMDG$\mathrm{Cl}$ group obtained before NMDG-Cl exposure are not shown for clarity. Here and in subsequent similar figures, the ordinate (relative area) represents the value of the cell area relative to that obtained in the control solution, and the abscissa represents elapsed time.

the cell shrinkage was $\mathrm{Na}^{+}$-independent and appeared to depend on $\left[\mathrm{K}^{+}\right]_{\mathrm{o}}$ in the recovery solution or $V_{\mathrm{m}}$, which should be determined by $\left[\mathrm{K}^{+}\right]_{\mathrm{o}}$. Similar experiments were performed with another solution having different $\left[\mathrm{K}^{+}\right]_{\mathrm{o}}$ and $\left[\mathrm{Cl}^{-}\right]_{\mathrm{o}}$ (Fig. 1B). The adrenergically swollen cells shrank also in $\mathrm{K}$-aspartate solution, which was $\mathrm{K}^{+}$-rich but $\mathrm{Cl}^{-}$deficient, indicating that the cell shrinkage does not absolutely depend on 


\section{S. YAMAMOTO et al.}

$\left[\mathrm{K}^{+}\right]_{\mathrm{o}}$ or $V_{\mathrm{m}}$. The common electrophysiological feature created by the transition from high- $\mathrm{KCl}$ solution to the three different solutions (normal Tyrode, NMDG-Cl, and K-aspartate solution) is the reversal of $E_{\mathrm{Cl}}-V_{\mathrm{m}}$ relationship. In the guinea pig ventricular cells immersed in the high- $\mathrm{KCl}$ solution, $V_{\mathrm{m}}$ is about $0 \mathrm{mV}$ [15], and $E_{\mathrm{Cl}}$ can be predicted to be near $-40 \mathrm{mV}$ [18-20]; thus $V_{\mathrm{m}}$ is positive to $E_{\mathrm{Cl}}$. In normal Tyrode and NMDG-Cl solution, both of which have $5.4 \mathrm{mM}$ $\left[\mathrm{K}^{+}\right]_{\mathrm{o}}, V_{\mathrm{m}}$ may be about $-85 \mathrm{mV}[15], E_{\mathrm{Cl}}$ remaining unchanged. In $\mathrm{K}$-aspartate solution, which contains a few $\mathrm{mM} \mathrm{Cl}^{-}, V_{\mathrm{m}}$ may be about $0 \mathrm{mV}$, but $E_{\mathrm{Cl}}$ should have a positive value. Thus in all the recovery solutions, $V_{\mathrm{m}}$ should be negative to $E_{\mathrm{Cl}}$, contrary to the situation in high- $\mathrm{KCl}$ solution. If some $\mathrm{Cl}^{-}$channels are active in the recovery solutions, an outward flux of $\mathrm{Cl}^{-}$ions (inward $\mathrm{Cl}^{-}$current) should occur through these channels, which would contribute to the cell shrinkage. Since the shrinkage occurred in the absence of $I_{\mathrm{Cl}, \mathrm{cAMP}}$ activator ( $\beta$-adrenergic agonist), and since the cells were initially in a swollen state, we hypothesized that the swelling-activated $\mathrm{Cl}^{-}$current $\left(I_{\mathrm{Cl}, \text { swell }}\right)$ played a role in the observed isosmotic cell shrinkage.

In Fig. 1 (see also Fig. 2A), it is noticeable that the cell swelling progressed in high- $\mathrm{KCl}$ solution after the withdrawal of adrenaline. One might argue that the activation of $I_{\mathrm{Cl}, \mathrm{cAMP}}$ would not rapidly subside upon a withdrawal of the drug and that the residual activity of $I_{\mathrm{Cl}, \mathrm{cAMP}}$ could contribute to the progress of cell swelling, and even to the subsequent cell shrinkage in the recovery solutions. However, the studies of current measurements have shown that cardiac $I_{\mathrm{Cl}, \mathrm{cAMP}}$ activated by $\beta$-adrenergic agonists deactivates completely within 1 min after elimination of the agonists $(12,14)$. According to our hypothesis, the progress of cell swelling without adrenaline seen in Fig. 1 could also be related to the flow of $I_{\mathrm{Cl} \text {,swell }}$ present in the already swollen cells.

To test this view, we examined the effects of the blockers of $I_{\mathrm{Cl}, \mathrm{swell}}$ (for review on $I_{\mathrm{Cl} \text {,swell }}$ blockers, see Okada [3] and Sorota [6]) on the changes in cell volume. Glibenclamide $(0.2 \mathrm{mM})$ and furosemide $(2 \mathrm{mM})$, which are nonspecific inhibitors of $I_{\mathrm{Cl} \text {,swell, signifi- }}$ cantly attenuated the shrinkage of adrenergically swollen cells in normal Tyrode solution (Fig. 2A). DIDS, a more specific inhibitor of $I_{\mathrm{Cl}, \text { swell }}$, also exerted a similar effect on the cell shrinkage (data not shown, but see figure 7 of [15]). The inhibitory effects of these compounds on the cell shrinkage were observed also in the experiments in which K-aspartate solution was used as a recovery solution (Fig. 1B). Although these inhibitors did not completely suppress the cell
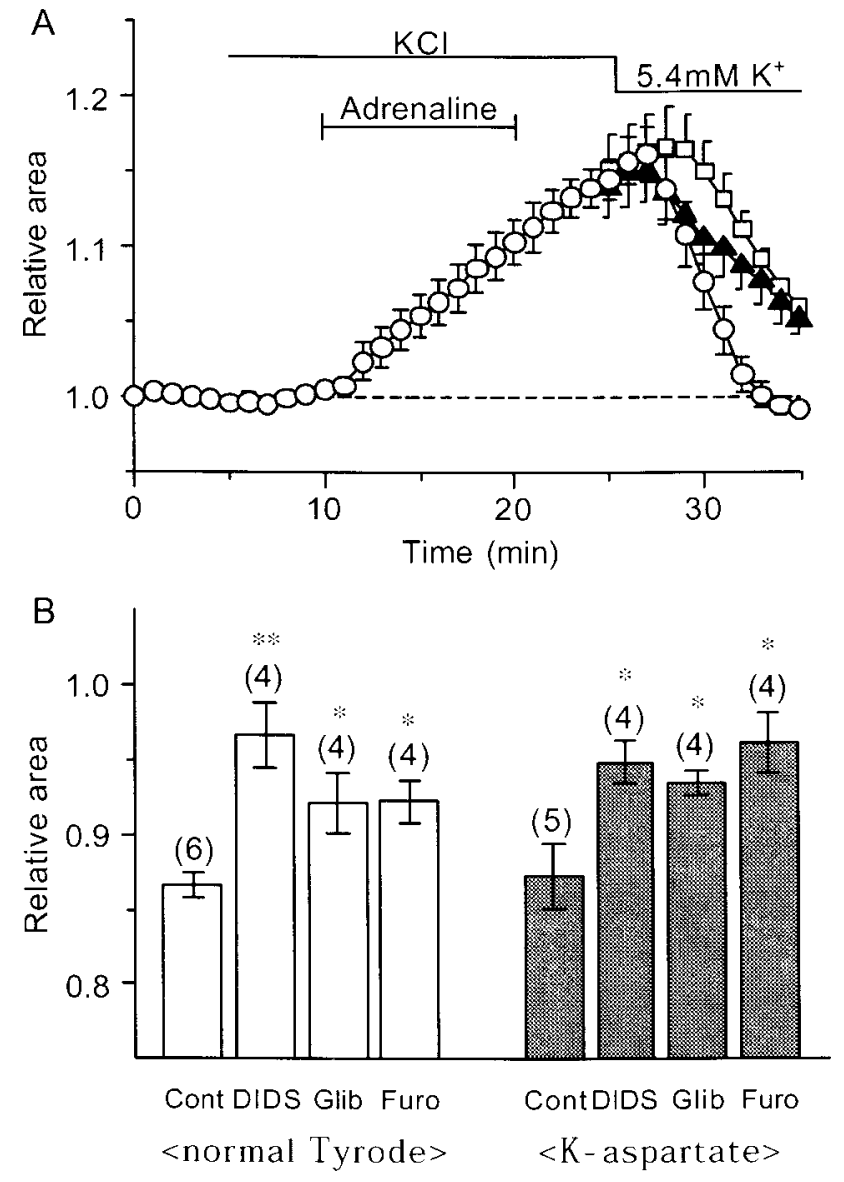

Fig. 2. A: Effects of $I_{\mathrm{Cl}, \text { swell }}$ inhibitors on the time course of the shrinkage of the adrenergically swollen cells. The cells were treated as in the experiments shown in Fig. 1 until exposure to the recovery solution. Then three types of recovery solutions were applied. One group of the cells (open circles, $n=4$ ) was exposed to normal Tyrode solution for control. The second group (squares, $n=5$ ) and the third one (triangles, $n=5$ ) were exposed to normal Tyrode solution containing glibenclamide $(0.2 \mathrm{mM})$ or furosemide $(2 \mathrm{mM})$, respectively. Each point represents mean \pm SEM. The data for the glibenclamide and furosemide groups obtained during exposure to high-K solution are not shown for clarity. B: Inhibitory effects of $I_{\mathrm{Cl}, \text { swell }}$ inhibitors on the cell shrinkage in normal Tyrode (left columns) and K-aspartate solution (right columns). Degree of cell shrinkage in the recovery solution (normal Tyrode or K-aspartate solution) was evaluated in the experiments like those shown in A. Each of these recovery solutions consisted of four types. One was drug-free (Cont), and the others contained $1 \mathrm{mM}$ DIDS (DIDS), $0.2 \mathrm{mM}$ glibenclamide (Glib), or $2 \mathrm{mM}$ furosemide (Furo). The data were obtained 10 min after the bathing solution was changed to the recovery solution and are expressed as relative to those obtained at the time of the solution change. The values represent mean \pm SEM. The numbers in parentheses are the number of the experiments. ${ }^{*}{ }^{* *}$ Significantly larger than control at $p<0.05$ and $p<0.01$, respectively. 
shrinkage, the results, which are summarized in Fig. $2 \mathrm{~B}$, support the view that an activity of $I_{\mathrm{Cl} \text {,swell }}$ channels contributed, at least partly, to the observed cell shrinkage.

\section{$I_{\mathrm{Cl}, \text { swell }}$ and RVD}

If a flow of $I_{\mathrm{Cl}, \text { swell }}$ activated by cell swelling can affect the cell volume, it is expected that the cells would exhibit RVD during hyposmotic cell swelling under conditions in which an inward $I_{\mathrm{Cl} \text {,swell }}$ can develop. We therefore examined this point under our experimental conditions. The cells were exposed to hyposmotic solution $\left(5.4 \mathrm{mM}\left[\mathrm{K}^{+}\right]_{\mathrm{o}}\right)$ with $70 \%$ osmolarity for 15 min. As shown in Fig. 3A, the cell area increased in hyposmotic solution, as expected. However, it peaked about $4 \mathrm{~min}$ after the beginning of hyposmotic perfusion, and there was a spontaneous decrease in cell area thereafter, the area obtained after more than 10 min being significantly smaller than the peak value. Such a spontaneous cell shrinkage was detected in almost every cell examined. Thus the cells appeared to undergo a definite, though small, RVD during hyposmotic challenge. It is very likely that the activation of $I_{\mathrm{Cl} \text {,swell }}$ contributed to the observed RVD in these cells. When isosmotic perfusion was resumed after the hyposmotic challenge, the cell area decreased, as expected. The level of cell area attained in the reapplied isosmotic solution was generally smaller than the control level, showing excessive cell shrinkage (Fig. 3A). The cell area remained at this low level without showing any recovery during the isosmotic perfusion, which continued for $10 \mathrm{~min}$ (Fig. 3A) or longer (up to 20 min, data not shown).

If $I_{\mathrm{Cl}, \text { swell }}$ contributes to RVD, a reduction of $\left[\mathrm{Cl}^{-}\right]_{\mathrm{o}}$ in the hyposmotic solution would facilitate the RVD, since a reduction of $\left[\mathrm{Cl}^{-}\right]_{\mathrm{o}}$ will shift $E_{\mathrm{Cl}}$ to a more positive voltage, which should increase the outward electrochemical driving force for $\mathrm{Cl}^{-}$ions across the membrane and thus increase the inward $I_{\mathrm{Cl}, \text { swell }}$ (outward $\mathrm{Cl}^{-}$flux). As shown in Fig. 3B, a reduction of $\left[\mathrm{Cl}^{-}\right]_{\mathrm{o}}$ to $10 \mathrm{mM}$, from $110 \mathrm{mM}$, during hyposmotic perfusion significantly enhanced the spontaneous decrease in cell area, in accordance with the above view.

To further confirm the flow of $I_{\mathrm{Cl} \text {,swell }}$ in hyposmotically swollen cells, we attempted to reverse the $E_{\mathrm{Cl}}-V_{\mathrm{m}}$ relationship during hyposmotic challenge, using a high- $\mathrm{K}^{+}$hyposmotic solution. In the standard hyposmotic solution $\left(5.4 \mathrm{mM}\left[\mathrm{K}^{+}\right]_{\mathrm{o}}\right.$ and $\left.110 \mathrm{mM}\left[\mathrm{Cl}^{-}\right]_{\mathrm{o}}\right), V_{\mathrm{m}}$ of the cells may be about $-85 \mathrm{mV}$ [15]. $E_{\mathrm{Cl}}$ can be assumed to be about $-30 \mathrm{mV}$, considering that $E_{\mathrm{Cl}}$ at $150 \mathrm{mM}\left[\mathrm{Cl}^{-}\right]_{\mathrm{o}}$ is about $-40 \mathrm{mV}[18-20]$ and that $E_{\mathrm{Cl}}$ value follows the Nernst equation. In the high- $\mathrm{K}^{+}$hyposmotic solution $\left(105.4 \mathrm{mM}\left[\mathrm{K}^{+}\right]_{\mathrm{o}}\right.$ and $106.4 \mathrm{mM}$
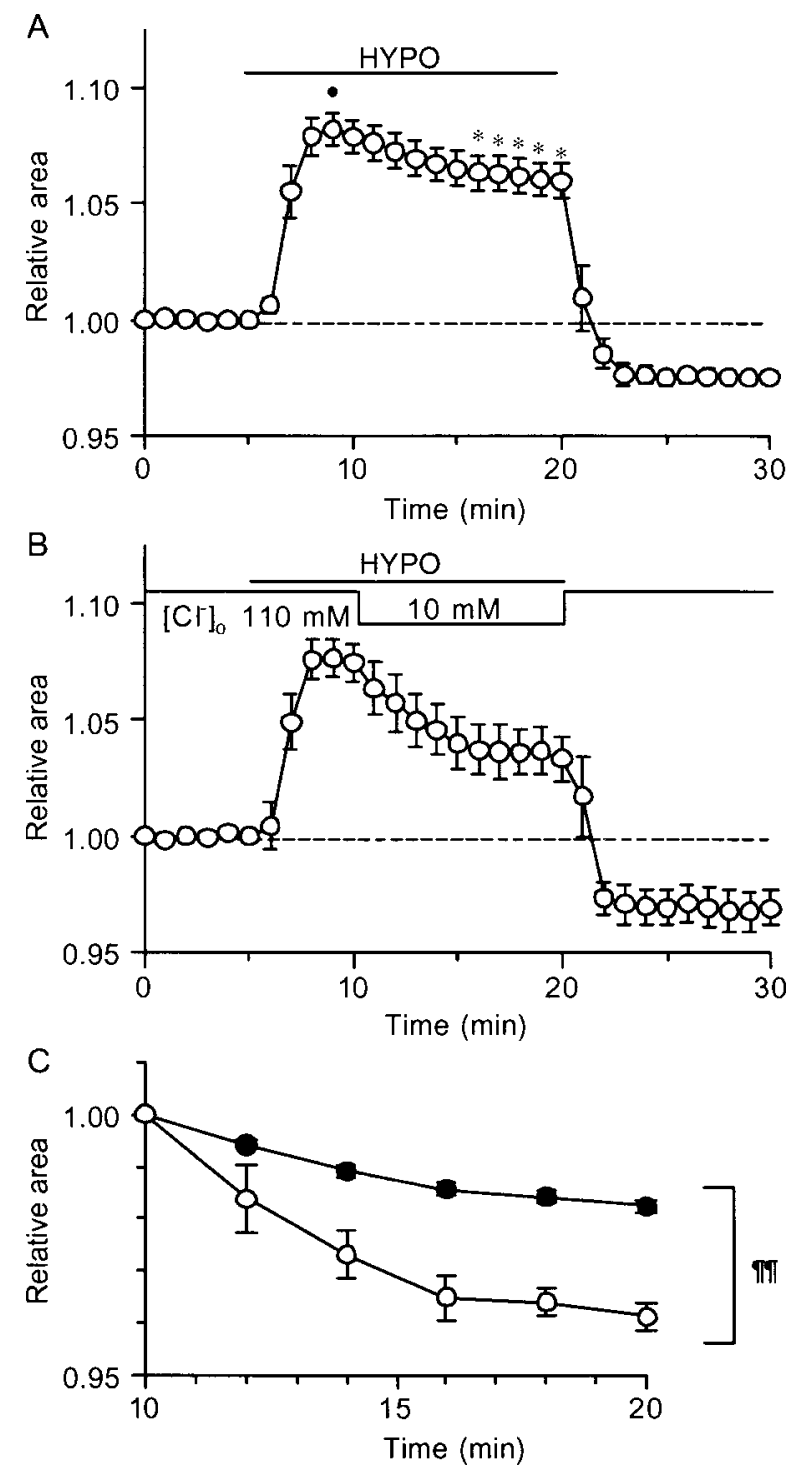

Fig. 3. Spontaneous cell shrinkage (regulatory volume decrease, RVD) observed during an application of hyposmotic solution and its enhancement in low- $\mathrm{Cl}^{-}$ hyposmotic solution. The cells were initially bathed in normal Tyrode solution, and hyposmotic (70\% of control) solution (HYPO) was then applied during the period indicated by the bar ( $A$ and $B$ ). Each point represents mean \pm SEM. A: Hyposmotic solution was the standard one with $110 \mathrm{~mm}$ $\left[\mathrm{Cl}^{-}\right]_{0}$, throughout $(n=7)$. * Significantly smaller than the cell area at the maximum cell swelling (denoted by dot) with $p<0.05$. B: $\left[\mathrm{Cl}^{-}\right]_{0}$ was lowered from 110 to $10 \mathrm{mM}$ during an application of hyposmotic solution, as indicated by the bar $(n=4)$. C: An expanded illustration of a part of A (closed circles) and a part of B (open circles). The values are expressed as relative to those obtained $5 \mathrm{~min}$ after an application of hyposmotic solution, at which time $\left[\mathrm{Cl}^{-}\right]_{0}$ was lowered in the experiments shown in $\mathrm{B}$. Each point represents mean \pm SEM. A comparison of curves with repeated measures ANOVA yielded $p<0.01$ ("ก). 


\section{S. YAMAMOTO et al.}

$\left.\left[\mathrm{Cl}^{-}\right]_{\mathrm{o}}\right), V_{\mathrm{m}}$ may be about $-10 \mathrm{mV}$ [15] and $E_{\mathrm{Cl}}$, about $-30 \mathrm{mV}$. Thus in this solution, $E_{\mathrm{Cl}}$ is negative to $V_{\mathrm{m}}$. Therefore, if the cells are exposed to this type of hy-

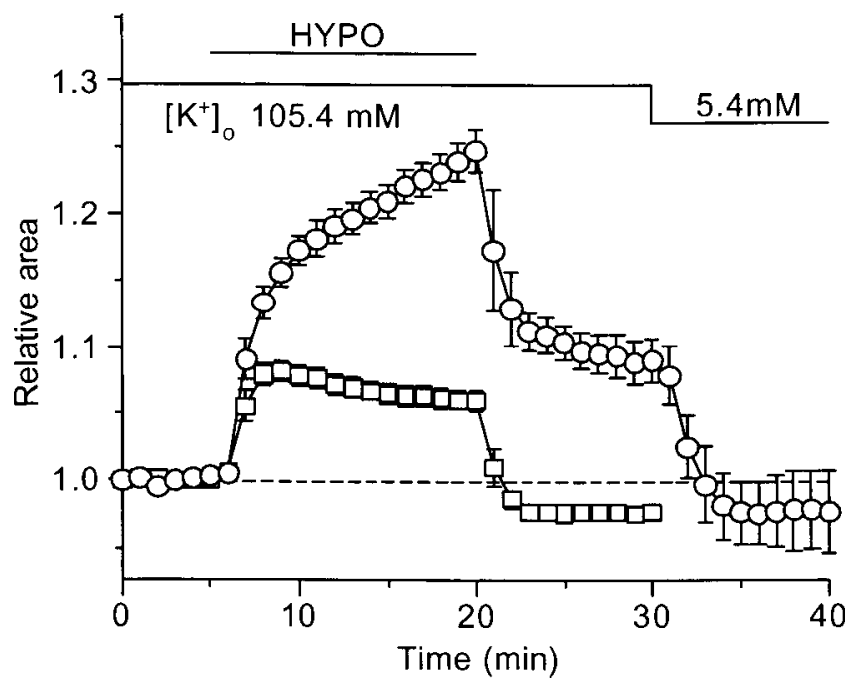

Fig. 4. Enhancement of hyposmotic cell swelling in high- $\mathbf{K}^{+}$solution (open circles). The cells were initially bathed in isosmotic high- $\mathrm{K}^{+}$solution $\left(105.4 \mathrm{mM}\left[\mathrm{K}^{+}\right]_{0}\right.$; lower bar), and were exposed to hyposmotic (70\% of control) high- $\mathrm{K}^{+}$solution (HYPO) for the period indicated by a bar. The bathing solution was finally switched to normal Tyrode solution with $5.4 \mathrm{mM}\left[\mathrm{K}^{+}\right]_{0}$. Each point represents mean \pm SEM $(n=5)$. For comparison, the data obtained at normal $\left[\mathrm{K}^{+}\right]_{0}$, which are shown in Fig. $3 \mathrm{~A}$, are reproduced in this figure (squares). posmotic solution, the $I_{\mathrm{Cl}, \text { swell }}$ channels activated by cell swelling should allow an outward flow of $I_{\mathrm{Cl}, \text { swell }}$ (inward $\mathrm{Cl}^{-}$flux) instead of an inward flow, which would lead to further cell swelling. The results of the experiments shown in Fig. 4 confirmed these notions. The cell area vigorously and monotonically increased during the hyposmotic challenge without showing any RVD, the degree of swelling being much greater than that seen at normal $\left[\mathrm{K}^{+}\right]_{0}$. Thus the cells exhibited an extra cell inflation in high- $\mathrm{K}^{+}$hyposmotic solution.

When isosmotic high- $\mathrm{K}^{+}$solution was resumed after the hyposmotic challenge, the cell area decreased, but it remained at a level larger than control for several min (Fig. 4). This may be explained at least partly by assuming that the amount of the intracellular solutes had increased during the preceding hyposmotic challenge because of $\mathrm{Cl}^{-}$influx (outward $\left.I_{\mathrm{Cl} \text {,swell }}\right)$ associated with the influxes of cations. Subsequently, the cell area returned to a level close to control upon an application of normal Tyrode (Fig. 4), representing an isosmotic cell shrinkage. In this process, the mechanism similar to that underlying the isosmotic cell shrinkage observed before (Figs. 1 and 2) may have been involved.

The involvement $I_{\mathrm{Cl} \text {,swell }}$ in the RVD at normal $\left[\mathrm{K}^{+}\right]_{\mathrm{o}}$ and in the extra cell inflation at high $\left[\mathrm{K}^{+}\right]_{\mathrm{o}}$ was further supported by the observation that DIDS attenuated both these cell responses (Fig. 5). When the hy-
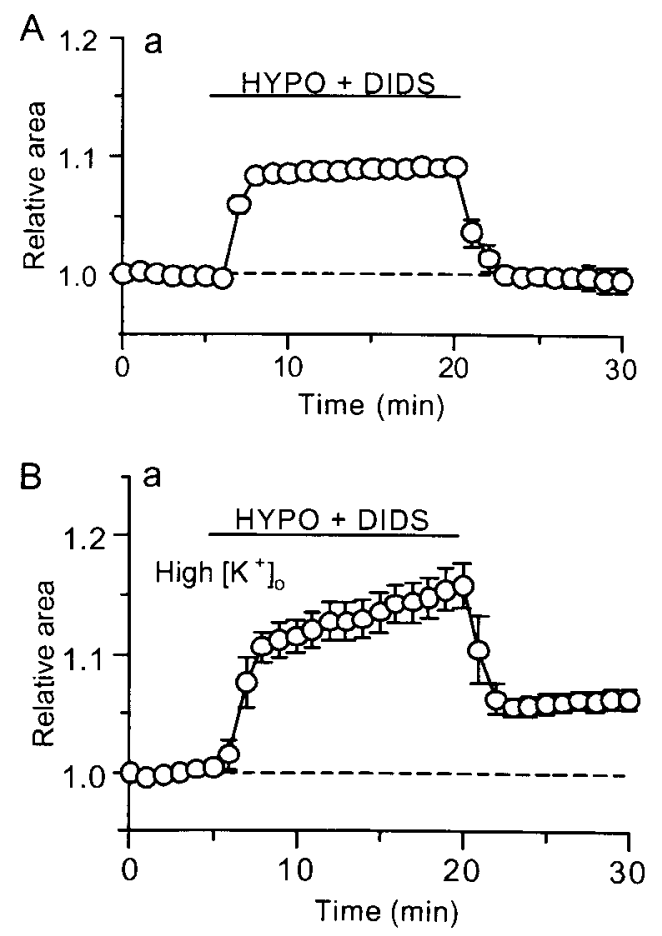
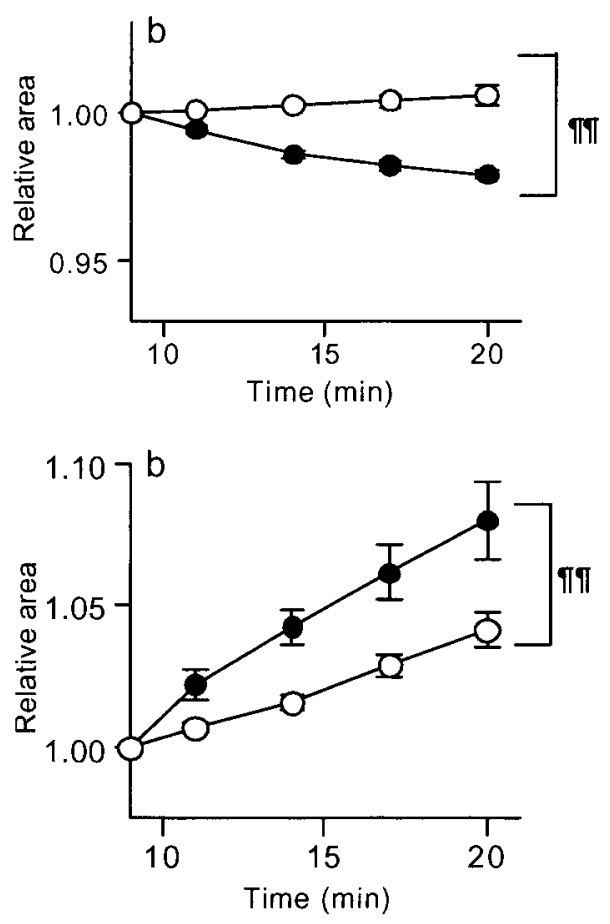

Fig. 5. Effects of DIDS on RVD (A) and the extra cell inflation induced by high- $\mathrm{K}^{+}$ hyposmotic solution (B). A: Normal Tyrode solution was replaced with standard hyposmotic solution ( $70 \%$ of control) containing $1 \mathrm{mM}$ DIDS for the period indicated by the bar. Each point represents mean \pm SEM $(n=4)$. Note that RVD did not develop here. B: The cells were initially bathed in isosmotic high- $\mathrm{K}^{+}$solution (105.4 mM $\left.\left[\mathrm{K}^{+}\right]_{0}\right)$ and were exposed to hyposmotic $(70 \%$ of control) high- $\mathrm{K}^{+}$solution containing $1 \mathrm{mM}$ DIDS for the period indicated by bar. Each point represents mean \pm SEM $(n=5)$. A-b and B-b respectively show an expanded illustration of a part of $A$ and $B$ (open circles; test curve), supplemented with a control

curve (closed circles) where the control curve was derived from the data shown in Fig. 3A for A-b and from those shown in Fig. 4 for B-b. For both the test and control curves, the values are expressed as relative to those obtained 4 min after the beginning of hyposmotic perfusion. A comparison of curves with repeated measures ANOVA yielded $p<0.01$ ( ${ }^{1 \uparrow}$ ). 
posmotic solution contained $1 \mathrm{mM}$ DIDS in the experiments with normal $\left[\mathrm{K}^{+}\right]_{0}$, the cells did not exhibit RVD (Fig. 5A). When similar experiments with DIDS were performed at high $\left[\mathrm{K}^{+}\right]_{\mathrm{o}}$, the rate of development of the cell swelling during hyposmotic challenge was significantly slower than in the control cells (Fig. 5B), though the drug could not arrest the extra cell inflation.

\section{DISCUSSION}

$I_{\mathrm{Cl} \text {,swell }}$ has been identified in many types of cardiac cells including guinea pig ventricular cells (for review see Vandenberg et al. [5] and Sorota [6]). In the present study, we attempted to clarify the volume regulatory role of $I_{\mathrm{Cl} \text {,swell }}$ in these cardiac cells, based on the following hypothesis. If $I_{\mathrm{Cl}, \text { swell }}$ plays a significant role in the cell volume regulation, the $I_{\mathrm{Cl}, \text { swell }}$-related changes in cell volume should well reflect the feature of $I_{\mathrm{Cl}, \text { swell }}$ specified by given electrophysiological conditions. Under the conditions in which $I_{\mathrm{Cl}, \text { swell }}$ flows inwardly $\left(\mathrm{Cl}^{-}\right.$efflux $)$, the cells should shrink. On the contrary, if $I_{\mathrm{Cl}, \text { swell }}$ flows outwardly $\left(\mathrm{Cl}^{-}\right.$influx), the cells should inflate. The larger the driving force for $\mathrm{Cl}^{-}$ions across the membrane, the larger the $I_{\mathrm{Cl} \text {,swell }}$, which will produce a larger change in cell volume. In the present study, cell shrinkage and RVD were observed under the conditions in which an inward flow of $I_{\mathrm{Cl} \text {,swell }}$ was presumed (Figs. 1 and 3); however, a cell swelling developed under the conditions in which an outward flow of $I_{\mathrm{Cl} \text {,swell }}$ was presumed (Fig. 4). Shifting $E_{\mathrm{Cl}}$ to a more positive voltage by reducing $\left[\mathrm{Cl}^{-}\right]_{0}$, which was expected to increase the inward $I_{\mathrm{Cl}, \text { swell }}$, enhanced the RVD during hyposmotic challenge (Fig. 3). These findings are consistent with the above hypothesis. The observation of the inhibitory effects of $I_{\mathrm{Cl}, \text { swell }}$ inhibitors on the changes in cell volume (Figs. 2 and 5) also supports the involvement of $I_{\mathrm{Cl} \text {,swell }}$ in these cell responses. The elimination of RVD by DIDS in hyposmotic media observed in the present study (Fig. 5A) is in line with the observation on dog ventricular cells [11], in which a 9AC-induced extra cell swelling was observed during hyposmotic perfusion.

The flow of $\mathrm{Cl}^{-}$ions through $I_{\mathrm{Cl} \text {,swell }}$ channels must occur in association with the flows of cations, practically $\mathrm{K}^{+}$ions, to affect the cell volume. We consider that this flow of $\mathrm{K}^{+}$ions is provided mainly by inward rectifier $\mathrm{K}^{+}$channels because these channels are abundant in cardiac cell membrane and construct its main resting conductance. The question then is how the flow of $\mathrm{K}^{+}$ions is enabled. Without an activation of $I_{\mathrm{Cl}, \mathrm{swell}}, V_{\mathrm{m}}$ may be almost equal to the equilibrium potential of $\mathrm{K}^{+}\left(E_{\mathrm{K}}\right)$; thus the flow of $\mathrm{K}^{+}$may be minimal. The activation of $I_{\mathrm{Cl}, \text { swell }}$ tends to shift $V_{\mathrm{m}}$ toward $E_{\mathrm{Cl}}$, establishing a deviation of $V_{\mathrm{m}}$ from $E_{\mathrm{K}}$, and this deviation builds up a driving force for $\mathrm{K}^{+}$. Since the deviated $V_{\mathrm{m}}$ should always lie at a level between $E_{\mathrm{Cl}}$ and $E_{\mathrm{K}}$, the polarity of $I_{\mathrm{Cl}, \text { swell }}$ and that of the $\mathrm{K}^{+}$current are reversed, providing the $\mathrm{Cl}^{-}$and $\mathrm{K}^{+}$fluxes of the same direction. Thus a net flux of $\mathrm{KCl}$ occurs, which, with an obligatory water flux, causes the changes in cell volume. It should be noted that the

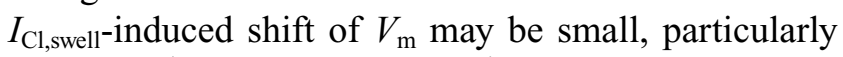
at high $\left[\mathrm{K}^{+}\right]_{\mathrm{o}}$ where the high $\mathrm{K}^{+}$conductance can suppress the polarizing effect of $I_{\mathrm{Cl}, \text { swell }}$ on the membrane. However, the magnitude of $\mathrm{K}^{+}$current $\left(\mathrm{K}^{+}\right.$flux $)$depends not only on the $V_{\mathrm{m}}$ shift; it is determined by a product of the $V_{\mathrm{m}}$ shift and the $\mathrm{K}^{+}$conductance. This point has been discussed in detail in the previous paper [15].

It has been shown that $I_{\mathrm{Cl}, \mathrm{cAMP}}$, another type of cardiac $\mathrm{Cl}^{-}$current can exert a volume-regulatory function in cardiac cells $[15,21]$. The activation of this current, like that of $I_{\mathrm{Cl}, \text { swell }}$, shrinks or inflates the cells, depending on $V_{\mathrm{m}}$ and $E_{\mathrm{Cl}}$. Thus two types of $\mathrm{Cl}^{-}$currents appear to contribute to the volume regulation in cardiac cells with a very similar mode of action. Since the volume regulation by these current systems involve only the passive transmembrane movements of ions and the osmotically driven water flux, cardiac cells seem to have two simple voltage-dependent volume-regulatory systems in parallel.

Both $I_{\mathrm{Cl} \text {,swell }}$ and $I_{\mathrm{Cl}, \mathrm{cAMP}}$ have a potential to inflate the cardiac cells under particular conditions. However, the physiological implication of this feature is hard to achieve, since an ionic situation in which $E_{\mathrm{K}}$ becomes positive to $E_{\mathrm{Cl}}$ may not develop under physiological conditions. Instead, the ability of these currents to shrink the cardiac cells at ordinary $\left[\mathrm{K}^{+}\right]_{0}$ might be important under pathological conditions [22]. During cardiac ischemia, cell swelling occurs [23-25], and the swelling disturbs coronary blood flow, which will further enhance the ischemia [26]. The swelling$I_{\mathrm{Cl}, \text { swell }}$ system, like the $\beta$-adrenoceptor- $I_{\mathrm{Cl}, \mathrm{cAMP}}$ system [21], can exert a beneficial effect on this situation by minimizing the cell swelling. A parallel operation of these two systems can develop in swollen cells. However, since $I_{\mathrm{Cl} \text {,swell }}$ inevitably activates in swollen cells without the need for external stimuli, and since $I_{\mathrm{Cl}, \mathrm{cAMP}}$ requires $\beta$-adrenergic stimulation for its activation, $I_{\mathrm{Cl} \text {,swell }}$ might play a primary role in the cellvolume regulation under ischemia, $I_{\mathrm{Cl}, \mathrm{cAMP}}$ playing a subsidiary role to facilitate the $I_{\mathrm{Cl}, \text { swell }}$ action in the presence of adrenergic tone. More studies are necessary to further specify the role of each current system 


\section{S. YAMAMOTO et al.}

and to clarify the cooperative feature of both systems in cell-volume regulation in cardiac cells.

The $I_{\mathrm{Cl}, \text { swell }}$ inhibitors did not completely suppress the recovery of adrenergically swollen cells in normal$\mathrm{K}^{+}$or low-Cl ${ }^{-}$solution (Fig. 2). Similarly, DIDS did not completely eliminate the extra cell inflation in high- $\mathrm{K}^{+}$hyposmotic solution (Fig. 5B). These findings might indicate the presence of $I_{\mathrm{Cl} \text {,swell }}$-independent cell-volume regulation, and it cannot be ruled out that the operation of such mechanisms more or less obscured the genuine $I_{\mathrm{Cl} \text {,swell }}$-related cell responses to be detected in the experiments. In relation to this, it should be noted that cardiac cells have several volume-regulatory systems, such as $\mathrm{Na}^{+}-\mathrm{H}^{+}$exchange, $\mathrm{Na}^{+}-\mathrm{K}^{+}$pump, $\mathrm{Na}^{+}-\mathrm{K}^{+}-2 \mathrm{Cl}^{-}$, and $\mathrm{K}^{+}-\mathrm{Cl}^{-}$cotransporters (for review see Wright and Rees [4] and Vandenberg et al. [5]). Obviously, an elucidation of the whole feature of cardiac cell-volume regulation requires a clarification of the role of these systems and a further characterization of the volume regulation involving $I_{\mathrm{Cl} \text {,swell }}$ and $I_{\mathrm{Cl}, \mathrm{cAMP}}$.

This work was supported in part by Grants-in-Aid for Scientific Research from the Ministry of Education, Science, Culture and Sports of Japan and the Salt Science Research Foundation (no. 00-02C3). S. Yamamoto is grateful to Professor Y. Hamasaki, Department of Pediatrics, Saga Medical School, for providing the opportunity to do this work. The secretarial assistance of Ms. M. Fuchigami is greatly appreciated.

\section{REFERENCES}

1. Sarkadi B and Parker JC: Activation of ion transport pathways by changes in cell volume. Biochim Biophys Acta 1071: 407-427, 1991

2. Strange K, Emma F, and Jackson PS: Cellular and molecular physiology of volume-sensitive anion channels. Am J Physiol 270: C711-C730, 1996

3. Okada Y: Volume expansion-sensing outward-rectifier $\mathrm{Cl}^{-}$channel: fresh start to the molecular identity and volume sensor. Am J Physiol 273: C755-C789, 1997

4. Wright AR and Rees SA: Cardiac cell volume: crystal clear or murky waters? A comparison with other cell types. Pharmacol Therap 80: 89-121, 1998

5. Vandenberg JI, Rees SA, Wright AR, and Powell T: Cell swelling and ion transport pathways in cardiac myocytes. Cardiovas Res 32: 85-97, 1996

6. Sorota S: Insights into the structure, distribution and function of the cardiac chloride channels. Cardiovas Res 42: 361-376, 1999

7. Zhang J, Rasmusson RL, Hall SK, and Lieberman M: A chloride current associated with swelling of cultured chick heart cells. J Physiol (Lond) 472: 801-820, 1993

8. Taouil $\mathrm{K}$ and Hannaert $\mathrm{P}$ : Evidence for the involvement of $\mathrm{K}^{+}$channels and $\mathrm{K}^{+}-\mathrm{Cl}^{-}$cotransport in the regulatory volume decrease of newborn rat cardiomyocytes. Pflügers Arch 439: 56-66, 1999

9. Suleymanian MA and Baumgarten CM: Osmotic gradi- ent-induced water permeation across the sarcolemma of rabbit ventricular myocytes. J Gen Physiol 107: 503514, 1996

10. Suleymanian MA, Clemo HF, Cohen NM, and Baumgarten CM: Stretch-activated channel blockers modulate cell volume in cardiac ventricular myocytes. J Mol Cell Cardiol 27: 721-728, 1995

11. Clemo HF, Stambler BS, and Baumgarten CM: Swelling-activated chloride current is persistently activated in ventricular myocytes from dogs with tachycardia-induced congestive heart failure. Circ Res 84: 157165, 1999

12. Bahinski A, Nairn AC, Greengard $P$, and Gadsby DC: Chloride conductance regulated by cyclic AMP-dependent protein kinase in cardiac myocytes. Nature 340: 718-721, 1989

13. Harvey RD and Hume JR: Autonomic regulation of a chloride current in heart. Science 244: 983-985, 1989

14. Matsuoka S, Ehara T, and Noma A: Chloride-sensitive nature of the adrenaline-induced current in guinea- pig cardiac myocytes. J Physiol (Lond) 425: 579-598, 1990

15. Yamamoto S, Ehara T, and Shioya T: Changes in cell volume induced by activation of the cyclic AMP-dependent chloride channel in guinea-pig cardiac myocytes. Jpn J Physiol 51: 31-41, 2001

16. Powell T, Terrar DA, and Twist VW: Electrical properties of individual cells isolated from adult rat ventricular myocardium. J Physiol (Lond) 302: 131-153, 1980

17. Isenberg $G$ and, Klöckner U: Calcium tolerant ventricular myocytes prepared by preincubation in a "KB medium." Pflügers Arch 395: 6-18, 1982

18. Tajima $Y$, Ono K, and Akaike N: Perforated patchclamp recording in cardiac myocytes using cation-selective ionophore gramicidin. Am J Physiol 271: C524C532, 1996

19. Tominaga $M$, Horie $M$, Sasayama $S$, and Okada $Y$ : Glibenclamide, an ATP-sensitive $\mathrm{K}^{+}$channel blocker, inhibits cardiac cAMP-activated $\mathrm{Cl}^{-}$conductance. Circ Res 77: 417-423, 1995

20. Ehara $T$ and Ishihara K: Anion channels activated by adrenaline in cardiac myocytes. Nature 347: 284-286, 1990

21. Wang Z, Mitsuiye T, Rees SA, and Noma A: Regulatory volume decrease of cardiac myocytes induced by $\beta$ adrenergic activation of the $\mathrm{Cl}^{-}$channel in guinea pig. J Gen Physiol 110: 73-82, 1997

22. Baumgarten $\mathrm{CM}$, and Clemo HF: Swelling-activated chloride channels in cardiac physiology and pathophysiology. Prog Biophys Mol Biol 82: 25-42, 2003

23. Macknight $A D$ and Leaf $A$ : Regulation of cellular volume. Physiol Rev 57: 510-573, 1977

24. Tranum-Jensen J, Janse MJ, Fiolet WT, Krieger, WJ, D'Alnoncourt CN, and Durrer D: Tissue osmolality, cell swelling, and reperfusion in acute regional myocardial ischemia in the isolated porcine heart. Circ Res 49: 364-381, 1981

25. Jennings RB, Schaper J, Hill ML, Steenbergen C Jr, and Reimer KA: Effect of reperfusion late in the phase of reversible ischemic injury. Changes in cell volume, electrolytes, metabolites, and ultrastructure. Circ Res 56: 262-278, 1985

26. Vogel WM, Cerel AW, and Apstein CS: Post-ischemic cardiac chamber stiffness and coronary vasomotion: the role of edema and effects of dextran. J Mol Cell Cardiol 18: 1207-1218, 1986 